\title{
Alternative Checkpoints as Targets for Immunotherapy
}

\author{
Ayush Pant ${ }^{1} \cdot$ Ravi Medikonda ${ }^{1} \cdot$ Michael Lim $^{1}$ \\ Accepted: 7 September 2020 / Published online: 3 November 2020 \\ (C) Springer Science+Business Media, LLC, part of Springer Nature 2020
}

\begin{abstract}
Purpose of Review Immunotherapy has shown an unprecedented response in treatment of tumors. However, challenges such as lack of cytotoxic lymphocytes to mount an immune response or development of resistance to therapy can limit efficacy. Here, we discuss alternative checkpoints that can be targeted to improve cytotoxic lymphocyte function while harnessing other components of the immune system.

Recent Findings Blockade of alternative checkpoints has improved anti-tumor immunity in mouse models and is being tested clinically with encouraging findings. In addition to modulating $\mathrm{T}$ cell function directly, alternative checkpoints can also regulate activity of myeloid cells and regulatory $\mathrm{T}$ cells to affect anti-tumor response.

Summary Combination of immune checkpoint inhibitors can improve treatment of tumors by activating multiple arms of the immune system.
\end{abstract}

Keywords Immunotherapy $\cdot$ Checkpoint blockade $\cdot$ Alternative checkpoints $\cdot \mathrm{T}$ cell exhaustion $\cdot$ Immunosuppression $\cdot$ Antigen presentation

\section{Introduction}

T cell dysfunction or "exhaustion" is a phenomenon that can result from chronic antigenic stimulation in the context of a tumor [1]. Broadly defined, exhaustion refers to a progressive loss of proliferative capacity, cytotoxicity, and inflammatory cytokine production. Exhausted T cells upregulate inhibitory molecules on the cell surface which mediate loss of effector function. Although T cell exhaustion can prevent immunopathology, autoreactivity, or $\mathrm{T}$ cell apoptosis in chronic antigen stimulation scenarios such as chronic viral infection, in the presence of a tumor, it can lead to immune evasion and tumor progression. Therefore, targeting inhibitory molecules such as cytotoxic T lymphocyte-associated protein 4 (CTLA-4) or programmed cell death protein-1 (PD-1) and their ligands has become a cornerstone of cancer immunotherapy [2].

This article is part of the Topical Collection on Immuno-oncology

Michael Lim

mlim3@jhmi.edu

1 Department of Neurosurgery, Neurosurgery Oncology, Radiation Oncology, Otolaryngology, and Institute of NanoBiotechnology, Brain Tumor Immunotherapy Program, Metastatic Brain Tumor Center, The Johns Hopkins University School of Medicine, $600 \mathrm{~N}$. Wolfe Street, Phipps 123, Baltimore, MD 21287, USA
Using immune checkpoint inhibitors (ICI) against PD-1 has generated unprecedented response in treating many solid tumors such as colon cancer, melanoma non-small cell lung cancer, and renal cell carcinoma [3]. Despite the success of ICIs in treating "hot" tumors that are inflamed and have infiltrating $\mathrm{T}$ cells that can be mobilized with ICIs, many "cold" tumors such as glioblastoma, prostate cancer, and pancreatic cancer are refractory to anti-PD-1 treatment due to a dearth of cytotoxic $\mathrm{T}$ lymphocytes (CTLs) in the tumor. Even within "hot" tumors, antiPD-1 therapy does not work for the majority of the patients, and those who respond initially are at risk of developing resistance to the therapy. This resistance is often accompanied by a concomitant increase in alternative checkpoint molecules such as LAG-3, TIM-3, VISTA, TIGIT, and $\mathrm{B} 7-\mathrm{H} 3$ in the tumor. As a result, our arsenal of ICIs is constantly expanding, with alternative checkpoints being targeted to prevent resistance and to stimulate $\mathrm{T}$ cell infiltration of "cold" tumors.

The multitude of studies exploring the blockade of these alternative checkpoints have revealed intricate interactions between these checkpoint molecules and non-CTLs including antigen-presenting cells (APCs), immunosuppressive cells, and $\mathrm{T}$ regulatory cells (Tregs). In this review, we will highlight the emerging alternative checkpoints and their effect on the lymphoid and myeloid compartments in cancer. 


\section{TIM-3 (T Cell Immunoglobulin Mucin-3)}

TIM-3 or hepatitis A virus cellular receptor 2 (HAVCR2) is an immune checkpoint that is present on CD4+ T cells, CD8+ T cells, NK cells, macrophages, dendritic cells (DCs), and B cells. Originally identified on the type 1 helper T cell (Th1) subset of CD4+ $\mathrm{T}$ cells as a suppressor of effector function in an autoimmune mouse model, it is now appreciated as a potent checkpoint molecule capable of mediating exhaustion among tumor-infiltrating CD8+ T cells [4]. Numerous animal studies have shown the efficacy of targeting TIM-3 along with PD-1 to reverse $T$ cell exhaustion and boost anti-tumor immunity [5, 6]. Analysis of immune cells from human tumors also corroborates the association between TIM-3 expression, T cell exhaustion, and poor prognosis [7-9]. Guided by these findings, there are many ongoing phase I and phase II clinical trials exploring dual TIM-3/PD-1 blockade in recurrent glioblastoma (NCT03961971), leukemia (NCT03066648), and advanced or metastatic solid tumors (AMBER, NCT02817633) as well as other tumors [10] (see Table 1).

What makes TIM-3 a unique candidate for immunotherapy is that it has multiple ligands including galectin-9 (Gal-9), carcinoembryonic antigen cell adhesion molecule (CEACAM-1), phosphotidylserine (PS), and high-mobility group protein B1 (HMGB-1) [11-14]. The function of TIM3 has been shown to vary depending on the specific receptorligand interaction (see Table 2). For example, TIM-3 can have both pro- and anti-inflammatory effects depending on which cell type it is present on and which ligand interacts with TIM3. TIM-3 on DCs, when ligated to galectin-9, can promote an inflammatory Th1 response. However, TIM-3 on Th1 cells can downregulate Th1 immune response when ligated with galectin-9 [15]. Furthermore, the interaction of galectin-9 with TIM3 + CD8+ T cells in an immunosuppressive context such as tumor microenvironment can promote effector function [16]; however, this same interaction in the context of an autoimmune or hyperimmune environment can promote $\mathrm{CD} 8+\mathrm{T}$ cell apoptosis [17].

Another ligand, HMGB1, illustrates the unique role of TIM-3 in suppressing antigen presentation. HMGB-1 is an alarmin produced by stressed and necrotic cells and is capable of binding immunogenic nucleic acids and recruiting them to $\mathrm{DC}$ endosomes for interaction with TLRs (Toll-like receptors) [18]. By binding HMGB1, TIM-3 can sequester it from activating TLRs. This reduces the immunogenicity of nucleic acids from dying tumor cells and plays a role in abrogating the benefit of DNA vaccines [19]. In contrast, phosphotidylserine is a ligand of TIM-3 exposed on the surface of apoptotic cells that stimulates TIM-3+ DCs to phagocytose the apoptotic cell and cross-present their antigens to $T$ cells [20].

By having such diverse and opposing functions depending on context, TIM-3 illustrates the necessity of considering not only the protein level of checkpoints on immune cells to determine optimal immunotherapy regimen but also the tumor microenvironment as a whole. This includes the availability of ligands, the context in which the ligand interacts with the checkpoint, and the nature of ongoing antigen presentation. Through optimization of treatment schedule, or improvements in local delivery of immunotherapy to tumor or draining lymph node, or co-blockade of select ligands along with the checkpoint molecule, we can improve cancer treatments by maximizing anti-tumor function while minimizing pro-tumor effects of checkpoint molecules.

\section{LAG-3 (Lymphocyte Activation Gene 3)}

LAG-3 is an inhibitory molecule expressed on activated T cells, NK cells, Tregs, plasmacytoid dendritic cells, and B cells. It is structurally similar to CD4 protein and is embedded in the CD4 locus. It binds to MHC II with a greater affinity than $\mathrm{CD} 4$, leading to early speculations that LAG-3 inhibits T cell activation by sequestering MHC II from binding to CD4 protein [21]. However, more recent studies have shown that the interaction between the extracellular region of LAG-3 and MHC II is neither universal nor sufficient to prevent $\mathrm{T}$ cell activation [22]. The study found that LAG-3 can only bind stable complexes of peptide-MHC II, and the intracellular regions of LAG-3 are indispensable for transducing an inhibitory signal. This provided a key piece of evidence linking LAG-3 to the maintenance of tolerance to dominant antigens, indicating the co-opting of this tolerance mechanism for cancer evasion despite the presence of immunogenic tumor antigens.

Although MHC II was long considered the canonical ligand, recent evidence shows that galectin-3, LSECtin (liver sinusoidal endothelial cell lectin), and fibrinogen-like protein 1 (FGL-1) interact with LAG-3 and negatively regulate $\mathrm{T}$ cell function $[23,24,25 \cdot \bullet]($ see Table 2). Due to its effect on $\mathrm{T}$ cell regulation, blocking LAG-3 has been tested in multiple mouse models of tumor and has shown significant synergy with PD-1 blockade [26-28]. In tumor-infiltrating $\mathrm{T}$ cells derived from patients, co-expression of LAG-3 and PD-1 was indicative of a greater exhaustion phenotype and worse prognosis than PD1 expression alone [29-31]. As a result, many clinical trials exploring combination LAG-3 and PD-1 blockade are currently underway. Indeed, the combination of anti-PD-1 with BMS-986016, a monoclonal antibody against LAG-3, has generated exciting results demonstrating clinical benefits in melanoma patients initially refractory to anti-PD-1 therapy [32••]. This combination is now being tested in multiple phase I and II trials for both hematological and solid malignancies.

A unique aspect of LAG-3 protein is that its transmembrane form can be cleaved by the ADAM10 and ADAM17 metalloproteases to a soluble form (s-LAG-3), which has 
Table 1 Summary of clinical trials evaluating alternate immune checkpoint targets presented in this review

\begin{tabular}{|c|c|c|c|c|c|c|}
\hline $\begin{array}{l}\text { Checkpoint } \\
\text { Inhibitor }\end{array}$ & Trial & Treatment arms & Phase & $\begin{array}{l}\text { Number } \\
\text { of } \\
\text { patients }\end{array}$ & Current status & Tumor \\
\hline \multicolumn{7}{|l|}{ anti-TIM-3 } \\
\hline & NCT03961971 & $\begin{array}{l}+ \text { Anti-PD-1 + stereotactic } \\
\text { radiosurgery }\end{array}$ & I & 15 & Active, not recruiting & Recurrent GBM \\
\hline & NCT03066648 & $\begin{array}{l}\text { Monotherapy } \\
+ \text { Decitabine } \\
+ \text { Anti-PD-1 } \\
\text { + Decitabine + anti-PD-1 } \\
\text { Decitabine + anti-PD-1 }\end{array}$ & I & 873 & Active, recruiting & Leukemia \\
\hline & NCT02817633 & $\begin{array}{l}\text { Monotherapy } \\
+ \text { Anti-PD-1 } \\
+ \text { Anti-LAG-3 }\end{array}$ & I & & Active, recruiting & Advanced or metastatic solid tumors \\
\hline \multicolumn{7}{|c|}{ LAG-3Ig fusion protein } \\
\hline & Brignone et al. [40] & $\begin{array}{l}\text { + Paclitaxel (for breast } \\
\text { cancer patients) }\end{array}$ & $\mathrm{I} / \mathrm{II}$ & 21 & Complete & $\begin{array}{l}\text { Advanced renal cell cancer and } \\
\text { metastatic breast cancer }\end{array}$ \\
\hline & Romano et al. [41] & $\begin{array}{l}\text { + MART- } 1 \text { analog peptide } \\
\text { vaccine }\end{array}$ & I & 12 & Complete & Advanced melanoma \\
\hline & Wang-Gilliam et al. [42] & + Gemcitabine & I & 18 & Complete & $\begin{array}{l}\text { Advanced pancreatic } \\
\text { adenocarcinoma }\end{array}$ \\
\hline Anti-LAG-3 & Ascierto et al. $[32 \bullet \bullet]$ & $\begin{array}{l}\text { Monotherapy } \\
+ \text { Anti-PD-1 }\end{array}$ & $\mathrm{I} / \mathrm{IIa}$ & 43 & Complete & Advanced melanoma \\
\hline \multicolumn{7}{|l|}{ anti-TIGIT } \\
\hline & NCT04294810 & $\begin{array}{l}\text { + Anti-PD-L1 } \\
\text { Placebo + anti-PD-L1 }\end{array}$ & III & 500 & Active, recruiting & Non-small cell lung cancer \\
\hline & NCT04256421 & $\begin{array}{l}\text { + Anti-PD-L1 + carboplatin } \\
\quad \text { + etoposide } \\
\text { Placebo + anti-PD-L1 + } \\
\quad \text { carboplatin + etoposide }\end{array}$ & III & 400 & Active, recruiting & Small cell lung cancer \\
\hline & NCT04047862 & + Anti-PD-1 & $\mathrm{I} / \mathrm{Ib}$ & 39 & Active, recruiting & Metastatic solid tumors \\
\hline & NCT04150965 & $\begin{array}{l}\text { Monotherapy } \\
+ \text { Pomalidomide + } \\
\text { dexamethasone } \\
\text { Anti-LAG-3 } \\
\text { Anti-LAG-3 + } \\
\text { pomalidomide + } \\
\text { dexamethasone } \\
\text { Elotuzumab (anti-SLAM-7) } \\
\quad \text { + pomalidomide + } \\
\text { dexamethasone }\end{array}$ & $\mathrm{I} / \mathrm{II}$ & 104 & $\begin{array}{l}\text { Active, not yet } \\
\text { recruiting }\end{array}$ & Multiple myeloma \\
\hline \multicolumn{7}{|l|}{ anti-VISTA } \\
\hline & NCT02812875 & None & I & 300 & Active, not recruiting & $\begin{array}{l}\text { Advanced solid tumors or } \\
\text { lymphomas }\end{array}$ \\
\hline \multicolumn{7}{|l|}{ anti-B7-H3 } \\
\hline & NCT02923180 & None & II & 33 & Active, not recruiting & Prostate cancer \\
\hline & NCT02475213 & $\begin{array}{l}\text { + Anti-PD-1 } \\
\text { (pembrolizumab or } \\
\text { MGA012) }\end{array}$ & $\mathrm{I}$ & 145 & Active, not recruiting & $\begin{array}{l}\text { Melanoma, head and neck cancer, } \\
\text { non-small cell lung cancer, } \\
\text { urothelial carcinoma }\end{array}$ \\
\hline & NCT03275402 & None & II/III & 32 & Active, recruiting & $\begin{array}{l}\text { Neuroblastoma, CNS metastases, } \\
\text { leptomeningeal metastases }\end{array}$ \\
\hline
\end{tabular}

immunomodulatory roles of its own. S-LAG-3 is released from activated T cells [33] or plasmacytoid DCs [34], and blocking cleavage of LAG-3 prevents further proliferation and activation of T cells [35]. However, the complete role of s-LAG-3 remains elusive. Findings from Triebel and colleagues show opposing effects of soluble LAG-3 on APC homeostasis. On the one hand, LAG-3-Ig (fusion of extracellular LAG-3 with IgG1 Fc portion) can mediate phenotypic maturation of DCs [36] and be used as a vaccine adjuvant to induce humoral and cellular immune response to antigens [37]. Once mature, these DCs secrete inflammatory cytokines and lose their capacity to capture further soluble antigens. On the other hand, the same group also showed that s-LAG-3 can prevent the differentiation of monocyte precursors to macrophages and dendritic cells, indicating that the positive effect of s-LAG-3 on DC maturation depends on the presence of pre-existing DCs [38]. Clinically, the use of IMP321, a soluble LAG-3 Ig, has shown robust induction of APC and CD8+ T cell function in advanced renal cell carcinoma and breast cancer [39-41], but not in pancreatic ductal adenocarcinoma (PDAC) [42]. To examine the 
Table 2 Summary of ligand-checkpoint interactions

\begin{tabular}{|c|c|c|c|c|}
\hline Ligand & Ligand + cell & Checkpoint + cell & Interaction context & Interaction outcome \\
\hline \multicolumn{5}{|l|}{ TIM-3 } \\
\hline \multicolumn{5}{|l|}{ Gal-9 } \\
\hline & $?$ & Th1 cells & $\begin{array}{l}\text { Hyperimmune } \\
\text { conditions }\end{array}$ & Apoptosis of TIM3+ cell [11] \\
\hline & Secreted by tumor & CD8+ T cells & Tumor & Apoptosis of TIM3+ cells [13] \\
\hline & Recombinant protein & DCs & Tumor & TIM3+ DC activates CD8+ T cells [16] \\
\hline \multicolumn{5}{|r|}{ 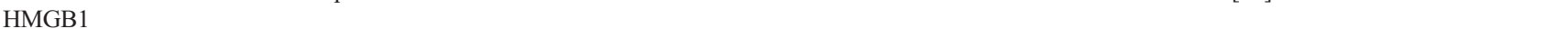 } \\
\hline & Extracellular protein & DCs & Tumor & $\begin{array}{l}\text { Nucleic acids released from tumor and bound to HMGB1 cannot } \\
\text { activate TLRs. Impaired antigen presentation [19] }\end{array}$ \\
\hline & Extracellular protein & $\begin{array}{l}\text { CD8+ Tregs in the } \\
\text { liver }\end{array}$ & $\begin{array}{l}\text { Hepatic necrosis } \\
\text { during infection }\end{array}$ & $\begin{array}{l}\text { CD8+ Tregs suppress activation of CD8+ T effector cells against } \\
\text { infection [14] }\end{array}$ \\
\hline PS & Apoptotic cells & CD8+ DCs & Apoptosis & $\begin{array}{l}\text { CD8+ DCs phagocytose apoptotic cells and cross-present antigens to } \\
\text { CD8+ T cells [20] }\end{array}$ \\
\hline CEACAM-1 & CD8+ T cells & CD8+ T cells & $\mathrm{T}$ cell homeostasis & $\begin{array}{l}\text { CEACAM-1 can form heterodimers with TIM-3 in trans or in cis, } \\
\text { potentiating TIM-3's inhibitory role [12] }\end{array}$ \\
\hline \multicolumn{5}{|r|}{ 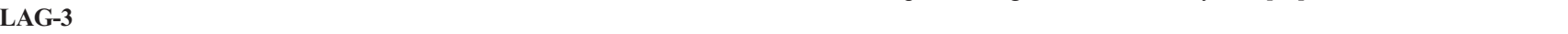 } \\
\hline MHC II & APCs & CD4+ T cells & $\mathrm{T}$ cell homeostasis & $\begin{array}{l}\text { LAG-3 bound to stable peptide-MHC II complex, suppressed T cell } \\
\text { activation [22] }\end{array}$ \\
\hline Gal-3 & $\begin{array}{l}\text { T cells and non-T } \\
\text { cells in TME }\end{array}$ & CD8+ T cells & Tumor & Activation of tumor-specific T cells suppressed [23] \\
\hline LSECtin & Tumor cells & $\mathrm{CD} 8+\mathrm{T}$ cells & Tumor & LSECtin induced on melanoma cells can suppress T cell activation [24] \\
\hline FGL-1 & $\begin{array}{l}\text { Secreted by some } \\
\text { tumors }\end{array}$ & CD8+ T cells & Tumor & Activation of antigen specific T cells suppressed [25••] \\
\hline MHC II & DC & Soluble LAG-3 & DC homeostasis & $\begin{array}{l}\text { Suppression of monocytic differentiation to DC [38] } \\
\text { and promotion of DC maturation [36] }\end{array}$ \\
\hline \multicolumn{5}{|r|}{ 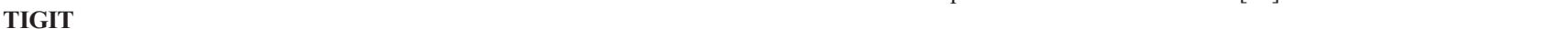 } \\
\hline CD155/PVR & DCs & $\begin{array}{l}\text { TIGIT-Fc fusion } \\
\text { protein }\end{array}$ & DTH & DCs exhibit tolerogenic changes, T cell priming reduced [47] \\
\hline CD122/PVRL2 & $\begin{array}{l}\text { Target cell for } \\
\text { cytotoxicity }\end{array}$ & NK cells & Immunosurveillance & Inhibition of NK cytotoxicity [46] \\
\hline \multicolumn{5}{|l|}{ VISTA } \\
\hline VSIG3 & $\begin{array}{l}\text { Immobilized } \\
\text { VSIG3-IgG1Fc }\end{array}$ & $\mathrm{T}$ cells & $\mathrm{T}$ cell homeostasis & Activation and proliferation of T cells inhibited [62] \\
\hline PSGL-1 & CD4+ T cells & $\begin{array}{l}\text { VISTA-Fc fusion } \\
\text { protein }\end{array}$ & T cell homeostasis & Activation and proliferation of T cells inhibited [63] \\
\hline $\begin{array}{l}\text { VISTA } \\
\text { (homophilic } \\
\text { binding) }\end{array}$ & $\begin{array}{l}\text { Apoptotic cells, } \\
\text { phagocytes, T cells }\end{array}$ & $\begin{array}{l}\text { Apoptotic cells, } \\
\text { phagocytes, T cells }\end{array}$ & $\begin{array}{l}\text { Phagocytosis/T cell } \\
\text { homeostasis }\end{array}$ & Apoptotic cells phagocytosed; T cell activation suppressed [64] \\
\hline \multicolumn{5}{|l|}{ B7-H3 } \\
\hline$?$ & ? & Tumor cells, APCs & Tumor & B7-H3 blockade improve anti-tumor response [81-83] \\
\hline
\end{tabular}

Gal-9 galectin-9

$H M G B 1$ high mobility group box 1

$P S$ phosphatidylserine

CEACAM-1 carcinoembryonic antigen-related cell adhesion molecule 1

Gal-3 galectin-3

TME tumor microenvironment

LSECtin liver and lymph node sinusoidal endothelial cell C-type lectin

$F G L-1$ fibrinogen-like protein 1

$P V R$ poliovirus receptor

$D T H$ delayed-type hypersensitivity

$P V R L 2$ poliovirus receptor-related 2

$V S I G 3 \mathrm{~V}$-set and Ig domain-containing protein 3

$P S G L-1$ P-selectin glycoprotein ligand-1

suitability of this therapy for a wider range of tumors including those that have a heavy presence of immunosuppressive myeloid cells such as glioblastoma [43] and PDAC [44•], it will be important to deconstruct the interplay between s-LAG-3, the presence of immunosuppressive myeloid precursors, and chronic antigen persistence. 
TIGIT (T Cell Immunoreceptor with Ig and ITIM Domains)

TIGIT, also known as VSTM3 or WUCAM, is an inhibitory molecule found on T cells, Tregs, and NK cells. It has been shown to mediate $\mathrm{T}$ cell dysfunction and is co-expressed with PD-1, LAG-3, and TIM-3 [45]. The ligands for TIGIT are CD155 (PVR or poliovirus receptor) and CD122 (PVRL2) [46]. TIGIT demonstrates multiple mechanisms of signaling. It can signal extracellularly by acting as a ligand for CD155 which is found on DCs. CD155 then promotes tolerogenic behavior in DCs by promoting secretion of antiinflammatory IL-10 and diminishing production of the p40 subunit of IL-12p40, thereby indirectly reducing T cell activation [47]. Another mechanism of TIGIT signaling involves interaction with CD155, which outcompetes the $\mathrm{T}$ cell cytotoxicity-promoting DNAM-1 protein from binding to CD155 [47, 48]. In doing so, TIGIT closely mimics the role of inhibitory CTLA-4 in preventing costimulatory CD28 from binding B7 ligand. Through its immunoreceptor tyrosinebased inhibition motif (ITIM) and immunoreceptor tail tyrosine-like (ITT-like) motif, TIGIT can also signal intracellularly to directly suppress $\mathrm{T}$ cell activation [49].

In murine tumor models, TIGIT is upregulated on tumorinfiltrating cells compared with cells from peripheral lymphoid organs $[45,50]$. Among the tumor-infiltrating CD8+ $\mathrm{T}$ cells, TIGIT is upregulated on severely dysfunctional cells that have the highest expression of PD-1, TIM-3, and the transcription factor Eomes, which is associated with terminally exhausted T cells [45]. Findings from Kurtulus et al. indicate that TIGIT + Tregs could promote severed dysfunction of $\mathrm{T}$ cells and show that TIGIT expression on Tregs drives the suppression of an anti-tumor response [45]. This highlights the potential of TIGIT blockade as a Treg-targeting therapy.

The use of TIGIT blockade alone [50] or in combination with anti-PD-1 therapy $[50,52]$ has shown efficacy in murine models of tumor. In human samples, TIGIT is upregulated in tumor-infiltrating lymphocytes, and co-expression with PD-1 and LAG-3 is associated with severe CD8+ T cell dysfunction and poor prognosis [50, 53-55]. In vitro assays using $\mathrm{T}$ cells derived from patients with multiple myeloma [51•] or advanced melanoma [54] have shown improvement in effector function following TIGIT blockade alone or with anti-PD-1 therapy, respectively. TIGIT upregulation on Tregs has also been correlated with poor clinical outcome following anti-PD1 and/or anti-CTLA-4 therapy [56]. Currently, there are clinical trials evaluating TIGIT blockade along with anti-PD-L1 therapy for non-small cell lung cancer (SKYCRAPER-01, NCT04294810), small cell lung cancer (SKYCRAPER-02, NCT04256421), or with anti-PD-1 therapy (NCT04047862) for metastatic solid tumors. Furthermore, newer trials in 2020 are exploring novel combinations; for example, a multiple myeloma trial is studying combination of TIGIT blockade with pomalidomide (NCT04150965). The results of these trials will be eagerly anticipated and can chart the role of TIGIT blockade in the management of other tumors as well.

\section{VISTA (V-Set Immunoglobulin Domain Suppressor of T Cell Activation)}

VISTA, also known as programmed death-1 homolog (PD$1 \mathrm{H})$, is a checkpoint molecule recently discovered to be involved in peripheral tolerance and T cell inactivation [57-59]. In addition to expression on T cells, VISTA is also found on myeloid cells and non-immune cells such as tumor cells. Unlike most other inhibitory molecules, VISTA does not need to be present on T cells to cause dysfunction. VISTA expression on cancer cells or APCs can also impair T cell activity $[60,61]$, warranting investigations of possible binding partners for VISTA used by T cells. Studies suggest VSIG3 is a ligand for VISTA [62], co-inhibitory PSGL-1 is a VISTAbinding partner [63], and VISTA can have homophilic interaction with VISTA on other cells [64].

In mouse tumor models, overexpression of VISTA on cancer cells has been associated with rapid tumor growth and impaired survival [59]. VISTA can be expressed on patientderived tumor cells as well, and high expression is associated with tumor progression [65] and lymph node metastasis [66] as well as T cell suppression [67]. Using VISTA blockade has shown pre-clinical anti-tumor efficacy [60, 67]. VISTA engagement in vitro has been shown to drastically reduce degranulation and cytokine production of tumor-infiltrating $\mathrm{T}$ cells isolated from pancreatic cancer patients [44]. What makes VISTA blockade more appealing is that its upregulation is implicated as a potential mechanism of acquired resistance in melanoma patients treated with anti-PD-1 [68.] and prostate cancer patients treated with anti-CTLA-4 therapy [69•]. Currently, CA-170, an orally available small molecule inhibitor of VISTA, is being tested in combination with PDL1/PD-L2 blockade in a phase I trial in patients with advanced tumors and lymphomas unresponsive to available therapies (NCT02812875). An anti-VISTA monoclonal antibody (JNJ-61610588) was also being examined clinically, but this study has been prematurely terminated.

\section{B7-H3}

B7-H3 (CD276) is a member of the B7 family of proteins that includes other members such as CD80, CD86, PD-L1 (B7H1), and VISTA. It is found on the surface of tumor cells, activated dendritic cells, and macrophages and allows them to modulate $\mathrm{T}$ cell response [70]. The receptor for $\mathrm{B} 7-\mathrm{H} 3$ has not been identified, and the role of B7-H3 signaling is controversial as it is reported to have both stimulatory $[70,71]$ and 
inhibitory effect on $\mathrm{T}$ cells $[72,73]$. A number of murine studies have shown an anti-tumor response elicited by B7H3 [74-76], but the expression of B7-H3 in human tumors correlates with poor prognosis, advanced pathological state, and metastasis in non-small cell lung cancer, pancreatic cancer, prostate cancer, and colorectal cancer [77-80]. The identification of counter receptors for B7-H3 on T cells could shed light on a seemingly context-dependent, contradictory role of B7-H3 on T cell homeostasis.

Despite the ambivalent results from correlative studies, blockade of B7-H3 with antagonistic antibodies has consistently demonstrated an anti-tumor response in mouse models [81-83]. While these studies indicate the blockade of B7-H3 on tumor cells or tumor-infiltrating DCs and macrophages enhance $\mathrm{T}$ cell function, there are non-immunological reasons to be hopeful about the efficacy of anti-B7-H3 therapy. B7-H3 on cancer cells has been shown to promote epithelialmesenchymal transition (EMT) which can maintain stem cell-like properties in tumor cells, aid in metastasis, and confer chemotherapy resistance $[84,85]$. Knockdown or blockade of B7-H3 expression reduces proliferative capacity of cancer cells, increases chemotherapy sensitivity, and compromises viability of cancer-initiating cells $[86,87]$. B7-H3 is also a tumor endothelial marker that is highly expressed during pathological angiogenesis and not physiological angiogenesis and can constitute tumor vasculature of colorectal cancer, esophageal cancer, non-small-cell lung cancer, breast cancer, and bladder cancer [88]. Because of its broad applicability to generating an anti-tumor response, B7-H3 blockade has entered several clinical trials. Antibodies against B7-H3 are currently being tested on patients with prostate cancer (NCT02923180), melanoma, head and neck cancer, non-small cell lung cancer and urothelial carcinoma (NCT02475213), neuroblastoma (NCT03275402), and many other tumors.

\section{Concluding Remarks}

The list of promising alternative checkpoints is not limited to the ones discussed above. The roles of other immune checkpoints like BTLA, Siglec-15, and newer B7 family members are being increasingly appreciated in dampening immune response and mediating tumor progression. While this review did not provide an exhaustive list of checkpoints or their mechanisms of action, it sought to present some common themes that the study of alternative checkpoint molecules has highlighted over recent years. While cancer immunotherapy is often considered a T cell-centric approach because of the prevalence of these markers on $\mathrm{T}$ cells, further examination has revealed that the regulatory roles of checkpoints extend beyond just $\mathrm{T}$ cells. These checkpoints can control the fate and function of other residents of the tumor microenvironment as well as of secondary lymphoid organs-from antigen-presenting cells to immunosuppressive cells to Tregs. TIM-3 and LAG-3, in addition to attenuating CD8+ $\mathrm{T}$ cell function, are now known to boost suppressor activity in Tregs $[89,90]$. Any therapeutic success from blocking these checkpoints could be attributed to inhibition of Tregs as much as to the alleviation of T cell exhaustion. Similarly, the efficacy of anti-TIM-3 or anti-TIGIT blockade might depend not only on the reversal of $\mathrm{T}$ cell exhaustion but also on the restoration of APC function and T cell priming, which could enhance T cell infiltration of "cold" tumors. Our understanding of the mechanism of action of the first generation of checkpoint molecules has also evolved. Recent work has shown PD-1 ablation on myeloid cells can have a greater anti-tumor effect than PD-1 ablation on T cells, by decreasing accumulation of myeloid precursors of MDSCs [91••]. Data from clinical trials have indicated that the efficacy of anti-PD-1 treatment might rely on recruitment of newly expanded clones of $\mathrm{T}$ cells into the tumor and that the pre-existing TILs have limited reinvigoration capacity $[92 \cdot \bullet, 93]$. While it is tempting to think of the above-mentioned alternative checkpoints solely in terms of their ability to shift PD-1+ $T$ cell along the activation-exhaustion spectrum, it is equally important to consider their impact across the different immune compartments. Such a holistic understanding can allow physicians to tailor immunotherapy regimen to the distinct immune niche of a particular tumor in individual patients.

\section{Compliance with Ethical Standards}

Conflict of Interest Ayush Pant and Ravi Medikonda declare that they have no conflict of interest. Michael Lim has received research support from Arbor Pharmaceuticals, Bristol-Myers Squibb, Accuray, DNATrix, Biohaven, and Kyrin-Kyowa; has received compensation for service as a consultant from Bristol-Myers Squibb, Tocagen, and Stryker; and has a patent issued on focused radiation + immunotherapy and a patent pending and licensed on local chemotherapy + immunotherapy.

Human and Animal Rights and Informed Consent This article does not contain any studies with human or animal subjects performed by any of the authors.

\section{References}

Papers of particular interest, published recently, have been highlighted as:

- Of importance

•- Of major importance

1. Blank CU, Haining WN, Held W, Hogan PG, Kallies A, Lugli E, et al. Defining 'T cell exhaustion. Nat Rev Immunol. 2019;19(11): 665-74. https://doi.org/10.1038/s41577-019-0221-9.

2. Sharma P, Allison JP. The future of immune checkpoint therapy. Science. 2015;348(6230):56-61. https://doi.org/10.1126/science. aaa8172. 
3. Pardoll DM. The blockade of immune checkpoints in cancer immunotherapy. Nat Rev Cancer. 2012;12(4):252-64. https://doi.org/ $10.1038 /$ nrc3239.

4. Zhu C, Sakuishi K, Xiao S, Sun Z, Zaghouani S, Gu G, et al. Correction: corrigendum: an IL-27/NFIL3 signalling axis drives Tim-3 and IL-10 expression and T-cell dysfunction. Nat Commun. 2015;6(1):7657. https://doi.org/10.1038/ncomms8657.

5. Sakuishi K, Apetoh L, Sullivan JM, Blazar BR, Kuchroo VK, Anderson AC. Targeting Tim-3 and PD-1 pathways to reverse T cell exhaustion and restore anti-tumor immunity. J Exp Med. 2010;207(10):2187-94. https://doi.org/10.1084/jem.20100643.

6. Kim JE, Patel MA, Mangraviti A, Kim ES, Theodros D, Velarde E, et al. Combination therapy with anti-PD-1, anti-TIM-3, and focal radiation results in regression of murine gliomas. Clin Cancer Res. 2017;23(1):124-36. https://doi.org/10.1158/1078-0432.CCR-151535.

7. Cheng G, Li M, Wu J, Ji M, Fang C, Shi H, et al. Expression of Tim-3 in gastric cancer tissue and its relationship with prognosis. Int J Clin Exp Pathol. 2015;8(8):9452-7 Retrieved from http:// www.ncbi.nlm.nih.gov/pubmed/26464703.

8. Japp AS, Kursunel MA, Meier S, Mälzer JN, Li X, Rahman NA, et al. Dysfunction of PSA-specific CD8+ T cells in prostate cancer patients correlates with CD38 and Tim-3 expression. Cancer Immunol Immunother. 2015;64(11):1487-94. https://doi.org/10. 1007/s00262-015-1752-y.

9. Li H, Wu K, Tao K, Chen L, Zheng Q, Lu X, et al. Tim-3/galectin-9 signaling pathway mediates $\mathrm{T}$-cell dysfunction and predicts poor prognosis in patients with hepatitis B virus-associated hepatocellular carcinoma. Hepatology. 2012;56(4):1342-51. https://doi.org/ 10.1002/hep.25777.

10. Qin S, Xu L, Yi M, Yu S, Wu K, Luo S. Novel immune checkpoint targets: moving beyond PD-1 and CTLA-4. Molecular Cancer BioMed Central Ltd. 2019;18:155. https://doi.org/10.1186/ s12943-019-1091-2.

11. Zhu C, Anderson AC, Schubart A, Xiong H, Imitola J, Khoury SJ, et al. The Tim-3 ligand galectin-9 negatively regulates $\mathrm{T}$ helper type 1 immunity. Nat Immunol. 2005;6(12):1245-52. https://doi.org/10. 1038/ni1271.

12. Huang Y-H, Zhu C, Kondo Y, Anderson AC, Gandhi A, Russell A, et al. CEACAM1 regulates TIM-3-mediated tolerance and exhaustion. Nature. 2015;517(7534):386-90. https://doi.org/10.1038/ nature 13848

13. Kang CW, Dutta A, Chang LY, Mahalingam J, Lin YC, Chiang $\mathrm{JM}$, et al. Apoptosis of tumor infiltrating effector TIM-3+CD8+ T cells in colon cancer. Sci Rep. 2015;5(1):1-12. https://doi.org/10. 1038/srep15659.

14. Dolina JS, Braciale TJ, Hahn YS. Liver-primed CD8+ T cells suppress antiviral adaptive immunity through galectin-9-independent T-cell immunoglobulin and mucin 3 engagement of high-mobility group box 1 in mice. Hepatology. 2014;59(4):1351-65. https://doi. org/10.1002/hep.26938.

15. Anderson AC, Lei C, Chandwaskar R, Karman J, Su EW, Hirashima M. Promotion of tissue inflammation by on innate immune cells. Science. 2011;1141(2007):9-12. https://doi.org/10. 1126/science. 1148536.

16. Nagahara K, Arikawa T, Oomizu S, Kontani K, Nobumoto A, Tateno H, et al. Galectin-9 increases Tim-3 + dendritic cells and CD8 + T cells and enhances antitumor immunity via galectin-9Tim-3 interactions. J Immunol. 2008;181:7660-9. https://doi.org/ 10.4049/jimmunol.181.11.7660.

17. Wang F, He W, Zhou H, Yuan J, Wu K, Xu L, et al. The Tim-3 ligand galectin-9 negatively regulates $\mathrm{CD} 8+$ alloreactive $\mathrm{T}$ cell and prolongs survival of skin graft. Cell Immunol. 2007;250:68-74. https://doi.org/10.1016/j.cellimm.2008.01.006.

18. Yanai H, Ban T, Wang Z, Choi MK, Kawamura T, Negishi H, et al. HMGB proteins function as universal sentinels for nucleic-acid- mediated innate immune responses. Nature. 2009;462(7269):99103. https://doi.org/10.1038/nature08512.

19. Chiba S, Baghdadi M, Akiba H, Yoshiyama H, Kinoshita I, Dosaka-Akita H, et al. Tumor-infiltrating DCs suppress nucleic acid-mediated innate immune responses through interactions between the receptor TIM-3 and the alarmin HMGB1. Nat Immunol. 2012;13(9):832-42. https://doi.org/10.1038/ni.2376.

20. Nakayama M, Akiba H, Takeda K, Kojima Y, Hashiguchi M, Azuma M, et al. Tim-3 mediates phagocytosis of apoptotic cells and cross-presentation. Blood. 2009;113:3821. https://doi.org/10. 1182/blood-2008-10.

21. Baixeras E, Huard B, Miossec C, Jitsukawa S, Martin M, Hercend $\mathrm{T}$, et al. Characterization of the lymphocyte activation gene 3encoded protein. A new ligand for human leukocy antigen class $\mathrm{h}$ antigens. J Exp Med. 1992;176:327-37. https://doi.org/10.1084/ jem.176.2.327.

22. Maruhashi T, Okazaki IM, Sugiura D, Takahashi S, Maeda TK, Shimizu K, et al. LAG-3 inhibits the activation of CD4 + T cells that recognize stable pMHCII through its conformation-dependent recognition of pMHCII. Nat Immunol. 2018;19:1415-26. https:// doi.org/10.1038/s41590-018-0217-9.

23. Kouo T, Huang L, Pucsek AB, Cao M, Solt S, Armstrong T, et al. Galectin-3 shapes antitumor immune responses by suppressing CD8 T cells via LAG-3 and inhibiting expansion of plasmacytoid dendritic cells. Cancer Immunol Res. 2015;3:412-23. https://doi. org/10.1158/2326-6066.CIR-14-0150.

24. Xu F, Liu J, Liu D, Liu B, Wang M, Hu Z, et al. LSECtin expressed on melanoma cells promotes tumor progression by inhibiting antitumor T-cell responses. Cancer Res. 2014;74:3418-28. https://doi. org/10.1158/0008-5472.CAN-13-2690.

25.• Wang J, Sanmamed MF, Datar I, Su TT, Ji L, Sun J, et al. Fibrinogen-like protein 1 is a major immune inhibitory ligand of LAG-3. Cell. 2019;176(1-2):334-347.e12. https://doi.org/10. 1016/j.cell.2018.11.010 This study discovered a major ligand for LAG-3 and showed that the ligand FGL1 is upregulated in some human cancers and associates with poot outcomes in anti-PD-1 treated patients. They also show blockade of LAG-3FGL1 interaction is therapeutic in mouse model of tumor.

26. Woo SR, Turnis ME, Goldberg MV, Bankoti J, Selby M, Nirschl CJ, et al. Immune inhibitory molecules LAG-3 and PD-1 synergistically regulate $\mathrm{T}$-cell function to promote tumoral immune escape. Cancer Res. 2012;72(4):917-27. https://doi.org/10.1158/00085472.CAN-11-1620.

27. Wierz M, Pierson S, Guyonnet L, Viry E, Lequeux A, Oudin A et al. Dual PD1/LAG3 immune checkpoint blockade limits tumor development in a murine model of chronic lymphocytic leukemia. Blood American Society of Hematology. 2018;131:1617-21. https://doi.org/10.1182/blood-2017-06-792267.

28. Harris-Bookman S, Mathios D, Martin AM, Xia Y, Kim E, Xu H, et al. Expression of LAG-3 and efficacy of combination treatment with anti-LAG-3 and anti-PD-1 monoclonal antibodies in glioblastoma. Int J Cancer. 2018;143(12):3201-8. https://doi.org/10.1002/ ijc.31661.

29. Yang ZZ, Kim HJ, Villasboas JC, Chen YP, Price-Troska TP, Jalali $\mathrm{S}$, et al. Expression of LAG-3 defines exhaustion of intratumoral PD-1+ T cells and correlates with poor outcome in follicular lymphoma. Oncotarget. 2017;8(37):61425-39. https://doi.org/10. 18632/oncotarget.18251.

30. Matsuzaki J, Gnjatic S, Mhawech-Fauceglia P, Beck A, Miller A, Tsuji T, et al. Tumor-infiltrating NY-ESO-1-specific CD8+ T cells are negatively regulated by LAG-3 and PD-1 in human ovarian cancer. Proc Natl Acad Sci U S A. 2010;107(17):7875-80. https://doi.org/10.1073/pnas.1003345107.

31. He Y, Yu H, Rozeboom L, Rivard CJ, Ellison K, Dziadziuszko R, et al. LAG-3 protein expression in non-small cell lung cancer and its relationship with PD-1/PD-L1 and tumor-infiltrating 
lymphocytes. J Thorac Oncol. 2017;12(5):814-23. https://doi.org/ 10.1016/j.jtho.2017.01.019.

32.• Ascierto PA, Melero I, Bhatia S, Bono P, Sanborn RE, Lipson EJ, et al. Initial efficacy of anti-lymphocyte activation gene-3 (antiLAG-3; BMS-986016) in combination with nivolumab (nivo) in pts with melanoma (MEL) previously treated with anti-PD-1/PDL1 therapy. J Clin Oncol. 2017;35(15_suppl):9520. https://doi.org/ $10.1200 /$ JCO.2017.35.15 suppl. 9520 This study shows preliminary clinical efficacy of using anti-LAG-3 therapy to improve anti-tumor response in patients with melanoma refractory to prior anti-PD-1. It highlights the clinical utility of using alternative checkpoint blockade to reduce resistance to antiPD-1 therapy.

33. Li N, Workman CJ, Martin SM, Vignali DAA. Biochemical analysis of the regulatory $\mathrm{T}$ cell protein lymphocyte activation gene-3 (LAG-3; CD223). J Immunol. 2004;173(11):6806-12. https://doi. org/10.4049/jimmunol.173.11.6806.

34. Workman CJ, Wang Y, El Kasmi KC, Pardoll DM, Murray PJ, Drake CG, et al. LAG-3 regulates plasmacytoid dendritic cell homeostasis. J Immunol. 2009;182:1885-91. https://doi.org/10.4049/ jimmunol.0800185.

35. Li N, Wang Y, Forbes K, Vignali KM, Heale BS, Saftig P, et al. Metalloproteases regulate T-cell proliferation and effector function via LAG-3. EMBO J. 2007;26(2):494-504. https://doi.org/10. 1038/sj.emboj.7601520.

36. Andreae S, Piras F, Burdin N, Triebel F. Maturation and activation of dendritic cells induced by lymphocyte activation gene-3 (CD223). J Immunol. 2002;168:3874-80. https://doi.org/10.4049/ jimmunol.168.8.3874.

37. El mir, S., \& Triebel, F. A soluble lymphocyte activation gene-3 molecule used as a vaccine adjuvant elicits greater humoral and cellular immune responses to both particulate and soluble antigens. J Immunol. 2000;164(11):5583-9. https://doi.org/10.4049/ jimmunol.164.11.5583.

38. Buisson S, Triebel F. LAG-3 (CD223) reduces macrophage and dendritic cell differentiation from monocyte precursors. Immunology. 2005;114:369-74. https://doi.org/10.1111/j.13652567.2004.02087.x.

39. Brignone C, Escudier B, Grygar C, Marcu M, Triebel F. A phase I pharmacokinetic and biological correlative study of IMP321, a novel MHC class II agonist, in patients with advanced renal cell carcinoma. Clin Cancer Res. 2009;15(19):6225-31. https://doi.org/10. 1158/1078-0432.CCR-09-0068.

40. Brignone C, Gutierrez M, Mefti F, Brain E, Jarcau R, Cvitkovic F, et al. First-line chemoimmunotherapy in metastatic breast carcinoma: combination of paclitaxel and IMP321 (LAG-3Ig) enhances immune responses and antitumor activity. J Transl Med. 2010;8: 71. https://doi.org/10.1186/1479-5876-8-71.

41. Romano E, Michielin O, Voelter V, Laurent J, Bichat H, Stravodimou A, et al. MART-1 peptide vaccination plus IMP321 (LAG-3Ig fusion protein) in patients receiving autologous PBMCs after lymphodepletion: results of a phase I trial. J Transl Med. 2014;12(1):97. https://doi.org/10.1186/1479-5876-12-97.

42. Wang-Gillam A, Plambeck-Suess S, Goedegebuure P, Simon PO, Mitchem JB, Hornick JR, et al. A phase i study of IMP321 and gemcitabine as the front-line therapy in patients with advanced pancreatic adenocarcinoma. Investig New Drugs. 2013;31(3): 707-13. https://doi.org/10.1007/s10637-012-9866-y.

43. de Groot J, Penas-Prado M, Alfaro-Munoz K, Hunter K, Pei BL, $\mathrm{O}$ 'Brien $\mathrm{B}$, et al. Window-of-opportunity clinical trial of pembrolizumab in patients with recurrent glioblastoma reveals predominance of immune-suppressive macrophages. NeuroOncology. 2020;22(4):539-49. https://doi.org/10.1093/neuonc/ noz185.

44. B Blando J, Sharma A, Higa MG, Zhao H, Vence L, Yadav SS, et al. Comparison of immune infiltrates in melanoma and pancreatic cancer highlights VISTA as a potential target in pancreatic cancer. Proc Natl Acad Sci U S A. 2019;116(5):1692-7. https://doi.org/10. 1073/pnas. 1811067116 This study analyzed tumor microenvironment of checkpoint blockade sensitive and resistant tumors (melanoma and pancreatic ductal adenocarcinomas respectively) and identified VISTA as a potent inhibitory checkpoint on tumor associated CD68+ macrophages in the pancreatic stroma.

45. Kurtulus S, Sakuishi K, Ngiow SF, Joller N, Tan DJ, Teng MWL, et al. TIGIT predominantly regulates the immune response via regulatory T cells. J Clin Investig. 2015;125(11):4053-62. https://doi. org/10.1172/JCI81187.

46. Stanietsky N, Simic H, Arapovic J, Toporik A, Levy O, Novik A, et al. The interaction of TIGIT with PVR and PVRL2 inhibits human NK cell cytotoxicity. Proc Natl Acad Sci U S A. 2009;106(42): 17858-63. https://doi.org/10.1073/pnas.0903474106.

47. Yu X, Harden K, Gonzalez LC, Francesco M, Chiang E, Irving B, et al. The surface protein TIGIT suppresses $\mathrm{T}$ cell activation by promoting the generation of mature immunoregulatory dendritic cells. Nat Immunol. 2009;10(1):48-57. https://doi.org/10.1038/ni. 1674.

48. Gilfillan S, Chan CJ, Cella M, Haynes NM, Rapaport AS, Boles $\mathrm{KS}$, et al. DNAM-1 promotes activation of cytotoxic lymphocytes by nonprofessional antigen-presenting cells and tumors. J Exp Med. 2008;205(13):2965-73. https://doi.org/10.1084/jem.20081752.

49. Joller N, Hafler JP, Brynedal B, Kassam N, Spoerl S, Levin SD, et al. Cutting edge: TIGIT has T cell-intrinsic inhibitory functions. J Immunol. 2011;186(3):1338-42. https://doi.org/10.4049/ jimmunol.1003081.

50. Hung AL, Maxwell R, Theodros D, Belcaid Z, Mathios D, Luksik AS, et al. TIGIT and PD-1 dual checkpoint blockade enhances antitumor immunity and survival in GBM. OncoImmunology. 2018;7(8). https://doi.org/10.1080/2162402X.2018.1466769.

51. Guillerey C, Harjunpää H, Carrié N, Kassem S, Teo T, Miles K, et al. TIGIT immune checkpoint blockade restores CD81 T-cell immunity against multiple myeloma. Blood. 2018;132(16):168994. https://doi.org/10.1182/blood-2018-01-825265 This study used in vitro stimulation of $T$ cells derived from Multiple Myeloma patients with anti-TIGIT antibodies to show it can improve effector function of $T$ cells. It also showed efficacy of TIGIT blockade in anti-tumor response using mouse model of multiple myeloma.

52. He W, Zhang H, Han F, Chen X, Lin R, Wang W, et al. CD155T/ TIGIT signaling regulates CD8+ T-cell metabolism and promotes tumor progression in human gastric cancer. Cancer Res. 2017;77(22):6375-88. https://doi.org/10.1158/0008-5472.CAN$17-0381$.

53. Lee WJ, Lee YJ, Choi ME, Yun KA, Won CH, Lee MW, et al. Expression of lymphocyte-activating gene 3 and T-cell immunoreceptor with immunoglobulin and ITIM domains in cutaneous melanoma and their correlation with programmed cell death 1 expression in tumor-infiltrating lymphocytes. J Am Acad Dermatol. 2019;81(1):219-27. https://doi.org/10.1016/j.jaad.2019. 03.012 .

54. Chauvin JM, Pagliano O, Fourcade J, Sun Z, Wang H, Sander C, et al. TIGIT and PD-1 impair tumor antigen-specific CD8+ T cells in melanoma patients. J Clin Investig. 2015;125(5):2046-58. https://doi.org/10.1172/JCI80445.

55. Kong Y, Zhu L, Schell TD, Zhang J, Claxton DF, Ehmann WC, et al. T-cell immunoglobulin and ITIM domain (TIGIT) associates with CD8+ T-cell exhaustion and poor clinical outcome in AML patients. Clin Cancer Res. 2016;22(12):3057-66. https://doi.org/10. 1158/1078-0432.CCR-15-2626.

56. Fourcade J, Sun Z, Chauvin JM, Ka M, Davar D, Pagliano O, et al. CD226 opposes TIGIT to disrupt Tregs in melanoma. JCI Insight. 2018;3(14). https://doi.org/10.1172/jci.insight.121157. 
57. Flies DB, Wang S, Xu H, Chen L. Cutting edge: a monoclonal antibody specific for the programmed death-1 homolog prevents graft-versus-host disease in mouse models. J Immunol. 2011;187(4):1537-41. https://doi.org/10.4049/jimmunol.1100660.

58. Han X, Vesely MD, Yang W, Sanmamed MF, Badri T, Alawa J, et al. PD-1H (VISTA)-mediated suppression of autoimmunity in systemic and cutaneous lupus erythematosus. Sci Transl Med. 2019;11(522):eaax1159. https://doi.org/10.1126/scitranslmed. aax1159.

59. Wang L, Rubinstein R, Lines JL, Wasiuk A, Ahonen C, Guo Y, et al. VISTA, a novel mouse Ig superfamily ligand that negatively regulates T cell responses. J Exp Med. 2011;208(3):577-92. https:// doi.org/10.1084/jem.20100619.

60. Lemercier I, Chen W, Lines JL, Day M, Li J, Sergent P, et al. VISTA regulates the development of protective anti-tumor immunity. Cancer Res. 2014;74(7):1933-44. https://doi.org/10.1158/ 0008-5472.CAN-13-1506.

61. Lines JL, Sempere LF, Broughton T, Wang L, Noelle R. VISTA is a novel broad-spectrum negative checkpoint regulator for cancer immunotherapy. Cancer Immunol Res. 2014;2(6):510-7. https:// doi.org/10.1158/2326-6066.CIR-14-0072.

62. Wang J, Wu G, Manick B, Hernandez V, Renelt M, Erickson C, et al. VSIG-3 as a ligand of VISTA inhibits human T-cell function. Immunology. 2019;156(1):74-85. https://doi.org/10.1111/imm. 13001.

63. Johnston RJ, Su LJ, Pinckney J, Critton D, Boyer E, Krishnakumar A, et al. VISTA is an acidic pH-selective ligand for PSGL-1. Nature. 2019;574(7779):565-70. https://doi.org/10.1038/s41586019-1674-5.

64. Yoon KW, Byun S, Kwon E, Hwang SY, Chu K, Hiraki M, et al. Control of signaling-mediated clearance of apoptotic cells by the tumor suppressor p53. Science. 2015;349(6247):1261669. https:// doi.org/10.1126/science.1261669.

65. Wu L, Deng WW, Huang CF, Bu LL, Yu GT, Mao L, et al. Expression of VISTA correlated with immunosuppression and synergized with CD8 to predict survival in human oral squamous cell carcinoma. Cancer Immunol Immunother. 2017;66(5):627-36. https://doi.org/10.1007/s00262-017-1968-0.

66. Liao H, Zhu H, Liu S, Wang H. Expression of V-domain immunoglobulin suppressor of $\mathrm{t}$ cell activation is associated with the advanced stage and presence of lymph node metastasis in ovarian cancer. Oncol Lett. 2018;16(3):3465-72. https://doi.org/10.3892/ ol.2018.9059.

67. Mulati K, Hamanishi J, Matsumura N, Chamoto K, Mise N, Abiko $\mathrm{K}$, et al. VISTA expressed in tumour cells regulates $\mathrm{T}$ cell function. Br J Cancer. 2019;120(1):115-27. https://doi.org/10.1038/s41416018-0313-5.

68. Kakavand H, Jackett LA, Menzies AM, Gide TN, Carlino MS, Saw RPM, et al. Negative immune checkpoint regulation by VISTA: a mechanism of acquired resistance to anti-PD-1 therapy in metastatic melanoma patients. Mod Pathol. 2017;30(12):1666-76. https:// doi.org/10.1038/modpathol.2017.89 This study identified VISTA as a potential mediator of acquired resistance to checkpoint blockade therapy in melanoma patients, solidifying VISTA's role as a druggable alternative checkpoint.

69. Gao J, Ward JF, Pettaway CA, Shi LZ, Subudhi SK, Vence LM, et al. VISTA is an inhibitory immune checkpoint that is increased after ipilimumab therapy in patients with prostate cancer. Nat Med. 2017;23(5):551-5. https://doi.org/10.1038/nm.4308 This study showed VISTA and PD-L1 levels increase on macrophages in anti-CTLA-4 treated tumors, further suggesting VISTA blockade can prevent resistance to immunotherapy.

70. Chapoval AI, Ni J, Lau JS, Wilcox RA, Flies DB, Liu D, et al. B7H3: a costimulatory molecule for $\mathrm{T}$ cell activation and IFN- $\gamma$ production. Nat Immunol. 2001;2(3):269-74. https://doi.org/10.1038/ 85339 .
71. Yan R, Yang S, Gu A, Zhan F, He C, Qin C, et al. Murine B7-H3 is a co-stimulatory molecule for $\mathrm{T}$ cell activation. Monoclon Antib Immunodiagn Immunother. 2013;32(6):395-8. https://doi.org/10. 1089/mab.2013.0052.

72. Suh WK, Gajewska BU, Okada H, Gronski MA, Bertram EM, Dawicki W, et al. The B7 family member B7-H3 preferentially down-regulates $\mathrm{T}$ helper type 1-mediated immune responses. Nat Immunol. 2003;4(9):899-906. https://doi.org/10.1038/ni967.

73. Prasad DVR, Nguyen T, Li Z, Yang Y, Duong J, Wang Y, et al. Murine B7-H3 is a negative regulator of T cells. J Immunol. 2004;173(4):2500-6. https://doi.org/10.4049/jimmunol.173.4. 2500.

74. Luo L, Chapoval AI, Flies DB, Zhu G, Hirano F, Wang S, et al. B7$\mathrm{H} 3$ enhances tumor immunity in vivo by costimulating rapid clonal expansion of antigen-specific CD8 + Cytolytic T cells. J Immunol. 2004;173(9):5445-50. https://doi.org/10.4049/jimmunol.173.9. 5445.

75. Lupu CM, Eisenbach C, Kuefner MA, Schmidt J, Lupu AD, Stremmel W, et al. An orthotopic colon cancer model for studying the B7-H3 antitumor effect in vivo. J Gastrointest Surg. 2006;10(5): 635-45. https://doi.org/10.1007/bf03239969.

76. Leitner J, Klauser C, Pickl WF, Stökl J, Majdic O, Bardet AF, et al. B7-H3 is a potent inhibitor of human T-cell activation: no evidence for B7-H3 and TREML2 interaction. Eur J Immunol. 2009;39(7): 1754-64. https://doi.org/10.1002/eji.200839028.

77. Zhang G, Xu Y, Lu X, Huang H, Zhou Y, Lu B, et al. Diagnosis value of serum B7-H3 expression in non-small cell lung cancer. Lung Cancer. 2009;66(2):245-9. https://doi.org/10.1016/j. lungcan.2009.01.017.

78. Yamato I, Sho M, Nomi T, Akahori T, Shimada K, Hotta K, et al. Clinical importance of B7-H3 expression in human pancreatic cancer. Br J Cancer. 2009;101(10):1709-16. https://doi.org/10.1038/sj. bjc. 6605375.

79. Zang X, Thompson RH, Al-Ahmadie HA, Serio AM, Reuter VE, Eastham JA, et al. B7-H3 and B7x are highly expressed in human prostate cancer and associated with disease spread and poor outcome. Proc Natl Acad Sci U S A. 2007;104(49):19458-63. https:// doi.org/10.1073/pnas.0709802104.

80. Sun J, Chen LJ, Zhang GB, Jiang JT, Zhu M, Tan Y, et al. Clinical significance and regulation of the costimulatory molecule B7-H3 in human colorectal carcinoma. Cancer Immunol Immunother. 2010;59(8):1163-71. https://doi.org/10.1007/s00262-010-0841-1.

81. Lee YH, Martin-Orozco N, Zheng P, Li J, Zhang P, Tan H, et al. Inhibition of the B7-H3 immune checkpoint limits tumor growth by enhancing cytotoxic lymphocyte function. Cell Res. 2017;27(8): 1034-45. https://doi.org/10.1038/cr.2017.90.

82. Yonesaka K, Haratani K, Takamura S, Sakai H, Kato R, Takegawa $\mathrm{N}$, et al. B7-h3 negatively modulates ctl-mediated cancer immunity. Clin Cancer Res. 2018;24(11):2653-64. https://doi.org/10.1158/ 1078-0432.CCR-17-2852.

83. Cai D, Li J, Liu D, Hong S, Qiao Q, Sun Q, et al. Tumor-expressed B7-H3 mediates the inhibition of antitumor T-cell functions in ovarian cancer insensitive to PD-1 blockade therapy. Cell Mol Immunol. 2020;17(3):227-36. https://doi.org/10.1038/s41423019-0305-2.

84. Jiang B, Zhang T, Liu F, Sun Z, Shi H, Hua D, et al. The costimulatory molecule B7-H3 promotes the epithelialmesenchymal transition in colorectal cancer. Oncotarget. 2016;7(22):31755-71. https://doi.org/10.18632/oncotarget.9035.

85. Shibue T, Weinberg RA. EMT, CSCs, and drug resistance: the mechanistic link and clinical implications. Nat Rev Clin Oncol Nature Publishing Group. 2017;14:611-29. https://doi.org/10. 1038/nrclinonc.2017.44.

86. Flem-Karlsen K, Tekle C, Andersson Y, Flatmark K, Fodstad Ø, Nunes-Xavier CE. Immunoregulatory protein B7-H3 promotes growth and decreases sensitivity to therapy in metastatic melanoma 
cells. Pigment Cell Melanoma Res. 2017;30(5):467-76. https://doi. org/10.1111/pcmr.12599.

87. Fauci JM, Sabbatino F, Wang Y, Londoño-Joshi AI, Straughn JM, Landen $\mathrm{CN}$, et al. Monoclonal antibody-based immunotherapy of ovarian cancer: targeting ovarian cancer cells with the B7-H3specific mAb 376.96. Gynecol Oncol. 2014;132(1):203-10. https://doi.org/10.1016/j.ygyno.2013.10.038.

88. Seaman S, Stevens J, Yang MY, Logsdon D, Graff-Cherry C, St. Croix B. Genes that distinguish physiological and pathological angiogenesis. Cancer Cell. 2007;11(6):539-54. https://doi.org/10. 1016/j.ccr.2007.04.017.

89. Gautron AS, Dominguez-Villar M, de Marcken M, Hafler DA. Enhanced suppressor function of TIM-3+FoxP3+ regulatory T cells. Eur J Immunol. 2014;44(9):2703-11. https://doi.org/10. 1002/eji.201344392.

90. Huang CT, Workman CJ, Flies D, Pan X, Marson AL, Zhou G, et al. Role of LAG-3 in regulatory T cells. Immunity. 2004;21(4): 503-13. https://doi.org/10.1016/j.immuni.2004.08.010.

91.• Strauss L, Mahmoud MAA, Weaver JD, Tijaro-Ovalle NM, Christofides A, Wang Q, et al. Targeted deletion of PD-1 in myeloid cells induces antitumor immunity. Sci Immunol. 2020;5: eaay1863. https://doi.org/10.1126/sciimmunol.aay1863 This study used T cell-specific and myeloid cell-specific PD-1 ablation and showed PD-1 on myeloid cells can contribute to dampening of antitumor immunity. Moreover, myeloidspecific deletion of PD-1 (and intact PD-1 on T cells) was as effective at controlling tumor growth as global ablation of PD1.

92.• Yost KE, Satpathy AT, Wells DK, Qi Y, Wang C, Kageyama R, et al. Clonal replacement of tumor-specific T cells following PD-1 blockade. Nat Med. 2019;25(8):1251-9. https://doi.org/10.1038/ s41591-019-0522-3 This study showed the expansion of $\mathbf{T}$ cells following anti-PD-1 therapy for basal and squamous cell carcinoma were of clones that were not in the tumor prior to treatment. This study indicates pre-existing tumor infiltrating $\mathrm{T}$ cells might lack rejuvination capacity following anti-PD-1 therapy and clinical response might depend on replacement with new $T$ cell clones.

93. Ghoneim, H. E., Fan, Y., Moustaki, A., Abdelsamed, H. A., Dash, P., Dogra, P., ... Youngblood, B. (2017). De novo epigenetic programs inhibit PD-1 blockade-mediated T cell rejuvenation. Cell, 170(1), 142-157.e19. https://doi.org/10.1016/j.cell.2017.06.007.

Publisher's Note Springer Nature remains neutral with regard to jurisdictional claims in published maps and institutional affiliations. 